\title{
FIRST RECORD OF IMPERIAL BLACKFISH, SCHEDOPHILUS OVALIS (ACTINOPTERYGII: PERCIFORMES: CENTROLOPHIDAE), FROM THE TUNISIAN COAST, CENTRAL MEDITERRANEAN
}

\author{
Sihem RAFRAFI-NOUIRA ${ }^{1}$, Daniel GOLANI ${ }^{2}$, Olfa EL KAMEL-MOUTALIBI ${ }^{1}$, \\ Moncef BOUMAÏZA ${ }^{1}$, Christian REYNAUD ${ }^{3}$, and Christian CAPAPÉ ${ }^{4 *}$ \\ ${ }^{1}$ Laboratoire d'Hydrobiologie Littorale et Limnique, Université de Carthage, Faculté des Sciences, Zarzouna, \\ Bizerte, Tunisia \\ ${ }^{2}$ Department of Evolution, Ecology and Behaviour, The Hebrew University of Jerusalem, Jerusalem, Israel \\ ${ }^{3}$ Laboratoire Interdisciplinaire de Recherche en Didactique, Éducation et Formation, Université Montpellier II, \\ Sciences et Techniques du Languedoc, Montpellier, France \\ ${ }^{4}$ Laboratoire d'Ichtyologie, Université Montpellier II, Sciences et Techniques du Languedoc, Montpellier, France
}

Rafrafi-Nouira S., Golani D., El Kamel-Moutalibi O., Boumaïza M., Reynaud C., Capapé C. 2015. First record of imperial blackfish, Schedophilus ovalis (Actinopterygii: Perciformes: Centrolophidae), from the Tunisian coast, central Mediterranean. Acta Ichthyol. Piscat. 45 (2): 203-206.

\begin{abstract}
Two specimens of imperial blackfish, Schedophilus ovalis (Cuvier 1829), were found for the first time off the Tunisian coast, in northern area. Both specimens are described, and occurrence of the species in the area and the Mediterranean Sea is discussed and commented.
\end{abstract}

Keywords: Osteichthyes, morphometric measurements, meristic counts, distribution, extension range

Imperial blackfish, Schedophilus ovalis (Cuvier 1833), is widely distributed in the eastern Atlantic from Spain to South African waters, and occurs also around Azores, Madeira, and Canaries Islands (Haedrich 1986, 1990). However, Haedrich (1986) and Fischer et al. (1987) wrongly reported that $S$. ovalis is present throughout the Mediterranean Sea. In the western Mediterranean Schedophilus ovalis is only known from the Balearic Islands (Deudero et al. 1999), Spain (Stefanescu and Massutí 1992), French waters, including Corsica (Francour and Javel 2003), and eastwards, to Italian waters (Orsi-Relini et al. 1990, Relini 1995, Psomadakis et al. 2006), including Sardinia (Follesa et al. 2006). In the eastern Mediterranean the fish has been reported from the Aegean Greek waters (Corsini-Foka and Frantzis 2009) and the Turkish Mediterranean coast, in Antalya Bay (Filiz and Güzelaydın 2014), and Iskanderun Bay (Erguden et al 2013); the coast of Israel being its easternmost extension range (Golani 1996, 2005).

Conversely, imperial blackfish is unknown to date from the south-eastern Mediterranean, and in this paper, the collection of two juvenile specimens off the Tunisian coast is reported. The first specimen was caught on 10 February 2011 at $2.5 \mathrm{~m}$ depth $\left(37^{\circ} 14^{\prime} 17.00^{\prime \prime} \mathrm{N}, 10^{\circ} 08^{\prime} 04.80^{\prime \prime} \mathrm{E}\right)$, and the second one on 11 February 2011, at $5 \mathrm{~m}$ depth $\left(37^{\circ} 14^{\prime} 28.77^{\prime \prime} \mathrm{N}, 10^{\circ} 07^{\prime} 32.21^{\prime \prime} \mathrm{E}\right)$. Both specimens were captured by trammel net of 26-mm stretched mesh size, on sandy rocky bottom partially covered by algae. They were preserved in $10 \%$ buffered formalin and deposited in the Ichthyological Collection of the Faculté des Sciences de Bizerte, receiving catalogue numbers FSB-Sche-ova-01 and FSB-Sche-ova-02, respectively (Fig. 1).

The identification of both specimens was carried out based on the following diagnosis: body deep and compressed, elongate oval shape, with greatest body depth at about vent; back and belly moderately arched; caudal peduncle short and deep; eye large surrounded by a low rim; lips thin; unpaired fins long and rather high, low anteriorly with short spines grading into longer branched rays. Colour dark grey to brownish with dark spots somewhat arranged in longitudinal lines.

Additionally, morphometric measurements were recorded to the nearest $1 \mathrm{~mm}$ and weighed to the nearest

\footnotetext{
"Correspondence: Dr Christian Capapé, Laboratoire d’Ichtyologie, case 104, Université Montpellier II, Sciences et Techniques du Languedoc, 34095 Montpellier cedex 5, France, (+33) 467544162, e-mail: (CC) capape@univ-montp2.fr, (SRN) sihem.rafrafi@yahoo.fr, (DG) dgolani@cc.huji.ac.il, (OEKM) elkamelolfa@yahoo.fr, (CC) reynaud@univ-montp2.fr.
} 


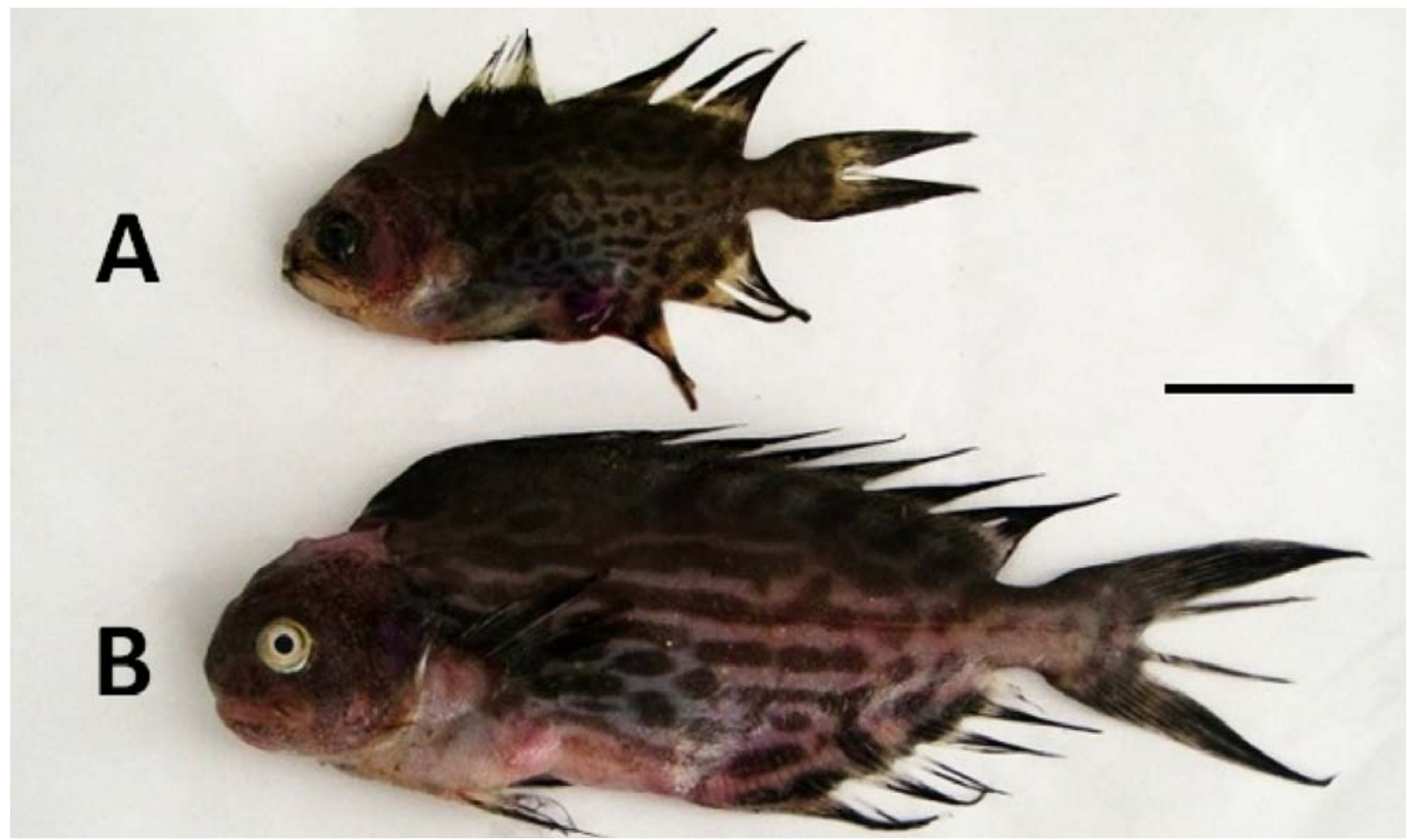

Fig. 1. Imperial blackfish, Schedophilus ovalis; Specimen referenced as FSB-Sche-ova-01 (A); Specimen referenced as FSB-Sche-ova-02 (B); Scale bar $=30 \mathrm{~mm}$

$1 \mathrm{~g}$, following Francour and Javel (2003); they are presented for both specimens in Tables 1 and 2. Morphology, morphometric measurements (in absolute values as well as expressed in percent of standard length), meristic counts, and colour are in agreement with previous descriptions of the species (Haedrich 1986, Orsi-Relini et al. 1990, Stefanescu and Massutí 1992, Psomadakis et al. 2006).
The presently reported two findings constitute the first records in the Tunisian waters of Schedophilus ovalis, which could be included in the Tunisian ichthyofauna, enlarging the number of fish species reported to date in the area (Bradai et al. 2004). Additionally, these findings constitute also the first records of the species in the southern Mediterranean Sea. Apart, from S. ovalis in Tunisian waters, another its congener- the Cornish blackfish, Schedophilus

Table 1

Absolute and relative values of selected morphometric measurements of both specimens of imperial blackfish, Schedophilus ovalis, collected off the north-eastern Tunisian coast

\begin{tabular}{lcccc}
\hline & \multicolumn{3}{c}{ Specimen } \\
\cline { 2 - 5 } \multicolumn{1}{c}{ Parameter } & \multicolumn{2}{c}{ FSB-Sche-ova-01 } & \multicolumn{2}{c}{ FSB-Sche-ova-02 } \\
\cline { 2 - 5 } & {$[\mathrm{mm}]$} & {$[\% \mathrm{SL}]$} & {$[\mathrm{mm}]$} & {$[\% \mathrm{SL}]$} \\
\hline Total length & 111 & 130.8 & 177 & 130.1 \\
Fork length & 91 & 107.6 & 144 & 105.5 \\
Standard length & 84 & 100.0 & 136 & 100 \\
Pre-dorsal fin length & 23 & 26.86 & 35 & 25.6 \\
Pre-pectoral fin length & 22 & 26.5 & 39 & 28.6 \\
Pre-anal fin length & 54 & 63.9 & 76 & 56.1 \\
Snout length & 8 & 9.7 & 11 & 8.0 \\
Eye diameter & 8 & 9.2 & 91 & 7.3 \\
Dorsal fin length & 52 & 61.0 & 11 & 66.9 \\
Pectoral fin length & 9 & 11.0 & 51 & 8.3 \\
Anal fin length & 29 & 33.9 & 51 & 37.5 \\
Body height & 33 & 39.5 & 20 & 37.5 \\
Caudal fin length & 13 & 15.3 & & 15.0 \\
\hline
\end{tabular}

$\mathrm{SL}=$ standard length. 
Table 2 due to the water warming. Similar pattern could explain the

Meristic counts and total body weight of both specimens of imperial blackfish, Schedophilus ovalis, collected off the north-eastern Tunisian coast

\begin{tabular}{lcc}
\hline \multirow{2}{*}{ Parameter } & \multicolumn{2}{c}{ Specimen } \\
\cline { 2 - 3 } & FSB-Sche-ova-01 & FSB-Sche-ova-02 \\
\hline Dorsal rays & VII +30 & VII +32 \\
Pectoral rays & I +5 & I +5 \\
Anal rays & III +24 & III +24 \\
Pectoral rays & 22 & 22 \\
Caudal rays & 19 & 19 \\
Total body weight $[\mathrm{g}]$ & 13.3 & 49.0 \\
\hline
\end{tabular}

medusophagus (Cocco, 1833) —was previously recorded by Bradai et al (2004). Schedophilus ovalis can be distinguished from S. medusophagus occurring in Tunisian waters by the presence of very strong spines in the median fins and body rigid, large scales, and the dorsal fin count (Haedrich 1986). Rigid and firm body of Schedophilus ovalis explicitly differs from the soft and limp body of S. medusophagus.

These new records of Schedophilus ovalis from Tunisia show that the species significantly extended southward its distribution in the Mediterranean Sea (Fig. 2). Francour and Javel (2003) noted that the species is regularly captured in north-western Mediterranean, offshore, around buoys or FADs, but did not constitute a dominant species in fish assemblages. Dulčić et al. $(1999,2012)$ and Francour and Javel (2003) noted an increase of captures in the Adriatic Sea and off the Mediterranean coast of France, probably recent occurrence of $S$. ovalis off the Tunisian coast.

However, the species has a pelagic way of life during juvenile stages and juveniles could be carried away by sea currents that probably play a more and less important role in widening its expansion throughout the Mediterranean. Yet, these two findings do not support that a sustainable population is a present established in its new region as in other Mediterranean areas (Francour and Javel 2003), therefore further and more records are needed to support such hypothesis.

\section{REFERENCES}

Bradai M.N., Quignard J.-P., Bouain A., Jarboui O., Ouannes-Ghorbel A., Ben Abdallah L., Zaouali J., Ben Salem S. 2004. Ichtyofaune autochtone et exotique des côtes tunisiennes: Recensement et biogéographie. Cybium 28 (4): 315-328.

Corsini-Foka M., Frantzis A. 2009. First documented record of imperial blackfish, Schedophilus ovalis (Actinopterygii: Perciformes: Centrolophidae), in the Aegean Greek waters. Acta Ichthyologica et Piscatoria 39 (1): 47-49.

DOI: 10.3750/AIP2009.39.1.09

Deudero S., Merella P., Morales-Nin B., Massutí E., Alemany F. 1999. Fish communities associated with FADs. Scientia Marina 63 (3-4): 199-207.

Dulčić J., Grbec B., Lipej L. 1999. Information on the Adriatic ichthyofauna-Effect of the water warming? Acta Adriatica 40 (2): 33-43.

Dulčić J., Skaramuca D., Dragičević B., Grgičević R., Bukvić V., Skaramuca B. 2012. On the additional oc-

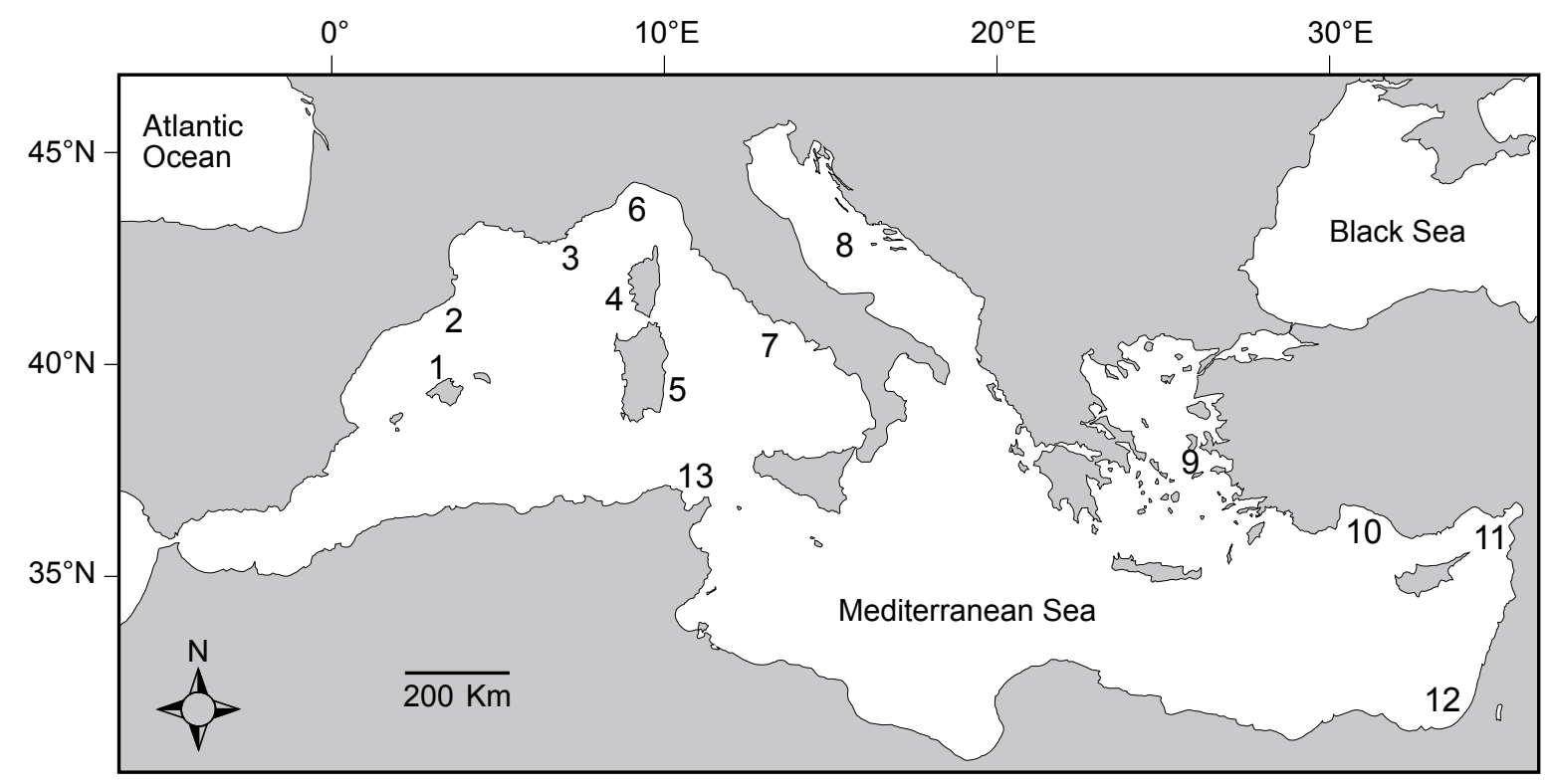

Fig. 2. Map of the Mediterranean Sea showing the capture sites of imperial blackfish, Schedophilus ovalis, recorded to date (from west to east): 1 = Balearic Islands (Deudero et al. 1999), 2 = Catalan Sea (Stefanescu and Massutí 1992), $3=$ Southern France (Francour and Javel 2003), $4=$ Corsica (Francour and Javel 2003), $5=$ Sardinia (Follesa et al. 2006), 6 = Ligurian Sea (Orsi-Relini et al. 1990), $7=$ Tyrrhenian Sea (Psomadakis et al. 2006), $8=$ Adriatic Sea (Dulčić et al. 1999, 2010), 9 = Aegean Sea of Greece (Corsini-Foka and Frantzis 2009), 10 = Turkish waters, Antalya Bay (Filiz and Güzelaydın 2014), 11 = Turkish waters, Iskenderun Bay (Erguden et al. 2013), 12 = Coast of Israel (Golani 1996, 2005), 13 = Tunisian waters (This study) 
currence of the imperial blackfish, Schedophilus ovalis (Cuvier, 1933) (Centrolophidae) in the Adriatic Sea. Annales Series Historia Naturalis 22 (1): 47-49.

Erguden D., Yaglioglu D., Turan C. 2013. Occurrence of Schedophilus ovalis (Cuvier, 1833) (Osteichthyes: Centrolophidae) in the north-eastern Mediterranean, Turkey. Journal of Applied Ichthyology 29 (1): 260-262.

DOI: 10.1111/jai.12037

Filiz H., Güzelaydın G. 2014. New additional record of imperial blackfish, Schedophilus ovalis (Cuvier, 1833) in the Turkish Mediterranean coast. Journal of Selçuk University Natural and Applied Science ICOEST Conf. 2014 (Part 2): 742-746.

Fischer W., Bauchot M.-L., Schneider M. 1987. Fiches FAO d'identification des espèces pour les besoins de la pêche. "Révision" Méditerranée et Mer Noire. Zone de Pêche 37. Vol. 2. Vertébrés. FAO, Rome.

Follesa M.C., Pais A., Cau A. 2006. Recent records of Schedophilus ovalis (Osteichthyes, Centrolophidae) from Sardinian waters (central-western Mediterranean). Biologia Marina Mediterranea 13 (1): 861-865.

Francour P., Javel F. 2003. Recent occurrences of young Schedophilus ovalis (Centrolophidae) along French Mediterranean coasts. Cybium 27 (1): 57-58.

Golani D. 1996. The marine ichthyofauna of the Eastern Levant-History, inventory, and characterization. Israel Journal of Zoology 42 (1): 15-55.

DOI: $10.1080 / 00212210.1996 .10688830$
Golani D. 2005. Checklist of the Mediterranean fishes of Israel. Zootaxa 2005 (947): 1-200.

Haedrich R.L. 1986. Centrolophidae. Pp. 1177-1182. In: Whitehead P.J.P., Bauchot M.-L., Hureau J.-C., Nielsen J., Tortonese E. (eds.) Fishes of the north-western Atlantic and the Mediterranean. Vol. 2. UNESCO, Paris.

Haedrich R.L. 1990. Centrolophidae. Pp. 1010-1013. In: Quéro J.C., Hureau M.L., Hureau J.-C., Karrer C., Tortonese E. (eds.) Check-list of the fishes of the eastern tropical Atlantic. Vol. 2. UNESCO, Paris.

Orsi-Relini L., Fida B., Relini M. 1990. Notes about Schedophilus ovalis (Osteichthyes, Centrolophidae) in the Ligurian sea. Rapports et Procès-verbaux de la Commission internationale pour l'exploration scientifique de la mer Méditerranée 32: 272.

Psomadakis P.N., Scacco U., Vacchi M. 2006. Recent findings of some uncommon fishes from the central Tyrrhenian Sea. Cybium 30 (4): 297-304.

Relini G. 1995. La fauna ittica batiale del Mediterraneo con particolare riferimento ai campionamenti dello strascico. Biologia Marina Mediterranea 2: 177-183.

Stefanescu C., Massutí E. 1992. Segunda cita de Schedophilus ovalis (Cuvier \& Valenciennes, 1833) (Osteichthyes, Centrolophidae) para el Mar Catalán (Mediterráneo NO). Miscellanea Zoologica 16: 240-242.

Received: 9 July 2014

Accepted: 21 December 2014

Published electronically: 30 June 2015 